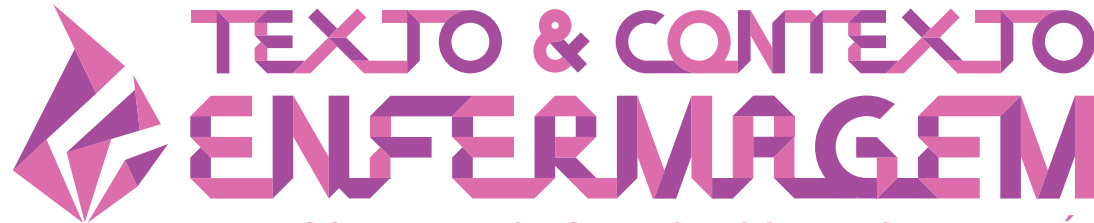

TEXT \& CONTEXT NURSING TEXTO \& CONTEXTO ENFERMERÍA

\section{EVALUATION OF HARM REDUCTION STRATEGIES IN THE PSYCHOSOCIAL CARE NETWORK}

\author{
Elitiele Ortiz dos Santos ${ }^{1}$ (1) \\ Leandro Barbosa de Pinho $^{2}$ \\ Adriane Domingues Eslabão ${ }^{2}$ \\ Rafael Gil Medeiros ${ }^{3}$
}

Universidade Federal do Pampa, curso de Medicina, Uruguaiana, Rio Grande do Sul, Brasil. ${ }^{2}$ Universidade Federal do Rio Grande do Sul, Programa de Pós-Graduação em Enfermagem. Porto Alegre, Rio Grande do Sul, Brasil. 3Universidade Federal do Rio Grande do Sul, Escola de Enfermagem. Porto Alegre, Rio Grande do Sul, Brasil.

\begin{abstract}
Objective: to evaluate harm reduction strategies in the Psychosocial Care Network of a small city in the southern region of Brazil.

Method: qualitative study, using the methodological assumptions of the Empowerment Evaluation. The research was carried out in the Psychosocial Care Network of a small city in Rio Grande do Sul, Brazil, from March to December 2017. Forty-two managers and workers of the psychosocial care network services and the intersectoral network for drug users participated in the study. Thematic analysis was used for data analysis.

Results: the mission of the network under study involved a work proposal aimed at harm reduction. In the knowledge of the current situation, the integrated action of the harm reduction team to the other services in the network was identified and the need for greater understanding of the specifics of this work. Concerning the perspectives for the future of the network, efforts were made to strengthen harm reduction strategies that redeem the potential of individuals and investments in human and structural resources in damage reduction teams.

Conclusion: the study presents support for the construction of harm reduction proposals integrated into the psychosocial care network, which can guide the prioritization of investments and improvements in the decision making of network managers and workers.
\end{abstract}

DESCRIPTORS: Mental health. Drug users. Harm reduction. Comprehensive health care. Health assessment. 


\section{AVALIAÇÃO DAS ESTRATÉGIAS DE REDUÇÃO DE DANOS NA REDE DE ATENÇÃO PSICOSSOCIAL}

\section{RESUMO}

Objetivo: avaliar as estratégias de Redução de danos na Rede de Atenção Psicossocial de um município do interior da região Sul do Brasil.

Método: estudo qualitativo, com a utilização dos pressupostos metodológicos da Avaliação de Empoderamento. A pesquisa foi realizada na Rede de Atenção Psicossocial de um município de pequeno porte do Rio Grande do Sul, Brasil, no período de março a dezembro de 2017. Participaram do estudo 42 gestores e trabalhadores inseridos nos serviços da rede de atenção psicossocial e da rede intersetorial ao usuário de drogas. Para análise dos dados utilizou-se a análise temática.

Resultados: a missão da rede em estudo envolveu uma proposta de trabalho na perspectiva da redução de danos. No Conhecimento da situação atual identificou-se a atuação integrada da equipe da redução de danos aos demais serviços da rede e a necessidade de maior compreensão sobre as especificidades desse trabalho. Nas perspectivas para o futuro da rede buscou-se fortalecer estratégias de redução de danos que resgatem as potencialidades dos sujeitos e os investimentos em recursos humanos e estruturais nas equipes de Redução de danos.

Conclusão: o estudo apresenta subsídios para a construção de propostas de redução de danos integradas à rede de atenção psicossocial, podendo orientar a priorização de investimentos e melhorias na tomada de decisão dos gestores e trabalhadores das redes.

DESCRITORES: Saúde mental. Usuários de drogas. Redução de dano. Assistência integral à saúde. Avaliação em saúde.

\section{EVALUACIÓN DE ESTRATEGIAS DE REDUCCIÓN DE DAÑOS EN LA RED DE ATENCIÓN PSICOSOCIAL}

\section{RESUMEN}

Objetivo: evaluar estrategias de reducción de daños en la Red de Atención Psicosocial de una ciudad del interior de la región sur de Brasil.

Método: estudio cualitativo, utilizando los supuestos metodológicos de la Evaluación de Empoderamiento. La investigación se llevó a cabo en la Red de Atención Psicosocial de una pequeña ciudad de Rio Grande do Sul, Brasil, de marzo a diciembre de 2017. Participaron del estudio 42 gerentes y trabajadores incluidos en los servicios de la red de atención psicosocial y la red intersectorial para los consumidores de drogas. El análisis temático se utilizó para el análisis de datos.

Resultados: la misión de la red en estudio involucró una propuesta de trabajo con perspectivas a la reducción de daños. En el Conocimiento de la situación actual, se identificó la acción integrada del equipo de reducción de daños con los demás servicios de la red y la necesidad de un mayor entendimiento de las especificidades de este trabajo. En las perspectivas de futuro de la red, se hicieron esfuerzos para fortalecer las estrategias de reducción de daños que rescatan el potencial de las personas y las inversiones en recursos humanos y estructurales en los equipos de reducción de daños.

Conclusión: el estudio presenta subsidios para la construcción de propuestas de reducción de daños integradas a la red de atención psicosocial, que pueden orientar la priorización de inversiones y mejoras en la toma de decisiones de los gestores y trabajadores de la red

DESCRIPTORES: Salud mental. Usuários de drogas. Reducción de daños. Atención integral de salud. Evaluación de la salud. 


\section{INTRODUCTION}

Harm Reduction (HR) strategies have been in practice for 30-years. The effectiveness of these strategies, although based on the impact on the harmful consequences of a particular type of psychoactive substance use, materialized in the exchange of inputs, was found not in the objectivity of the exchange, but in the acceptance of a type of inclusive care. HR promotes relationships with people who use drugs and the guarantee of access to preventive education strategies. ${ }^{1}$

Harm reduction interventions are implemented in different countries around the world and have significantly contributed to the reduction of viral infections, bacterial infections, and the reduction of crime. In addition, health cost reduction has been achieved where harm reduction strategies are in place. ${ }^{2-4}$

HR was the first movement to criticize the international model of drug prohibition, enabling concrete possibilities in the prevention of health problems. From the perspective of some evaluators, the War on Drugs proposal, over the years, has not shown to be effective, because in addition to making it difficult for the people who do not want or cannot stop using drugs, to adhere to the treatment, it has contributed to racial disparities and increased public spending. ${ }^{5}$

In the Brazilian context, HR actions are no longer an exclusive strategy of the Sexually Transmitted Diseases Programs (STDs) and have become guiding actions of the Ministry of Health's Comprehensive Care Policy for Users of Alcohol and other Drugs. This Policy recommends preventive actions and harm reduction and the intertwining of such initiatives with the Psychosocial Care Network (RAPS). ${ }^{6}$

In this perspective, HR was established as a public health strategy that integrates, in a transversal way, different services of the RAPS, be they basic or specialized care. However, in order to be effective, HR must be incorporated in interrelationships, expanding contact between users, services and teams, creating points of reference, enabling access and reception, knowledge of the territory, thus multiplying the possibilities of facing problems related to drug abuse. ${ }^{7}$

Even with the progress made with HR, its implementation is challenging due to the lack of funding for harm reduction practices, resulting in limited services within communities. Misinterpretation of the current HR policies, and the lack of involvement of other community devices with these strategies still exist. ${ }^{8-10}$

Thus, given the importance of qualifying the understanding of HR strategies - a guideline of the Brazilian mental health policy - to address the consumption of psychoactive substances, and considering the need to understand the challenges that this policy has regarding its operationalization in the health care networks, we propose to investigate the following guiding question: how are harm reduction strategies evaluated in the experience of workers and managers of a Psychosocial Care Network? The research aimed to evaluate the Harm Reduction strategies in the Psychosocial Care Network of a small city in the South of Brazil.

\section{METHOD}

This is an evaluative qualitative study using the methodological assumptions of the Empowerment Evaluation, which is characterized as a participatory assessment that uses concepts, principles, techniques and results to promote improvement and self-determination of interest groups, aiming to improve social technologies and programs. It aims to help people to evaluate their own programs through three integrated steps: 1st) Construction of the Mission; 2nd) Knowledge of the current situation; 3rd) Planning for the future. ${ }^{11}$

This research was carried out in a Psychosocial Care Network of a small city in Rio Grande do Sul, Brazil, selected intentionally for being a reference in terms of network care, from the perspective of community-based psychosocial care, and a pioneer in the implementation of Psychosocial Care Centers in Rio Grande do Sul. The interest groups in this study include RAPS service managers and workers. 
For the production of data, the design of an evaluative research with a participatory character was built, based on the triangulation of qualitative methods. Four techniques were used for data production: participant observation; semi structured interview; document analysis and open forum.

The participant observation involved an interaction process between the researcher and the evaluation activities in the network under study, when the right of entry for the research was obtained and the components and sectors involved with the work in the local RAPS were identified. The observation took place from March to December 2017, using field diary records.

The documentary analysis involved the search for documents regarding the work of the RAPS, including the minutes of the CAPS AD III team meetings and matrix support meetings. The purpose of the analysis was to broaden the understanding of the network in question.

Semi-structured interviews were applied to 42 professionals from the following components of the RAPS: 18 workers from the primary health care component (harm reduction, central health unit, ESF, and NASF); nine from strategic psychosocial care (CAPS AD, CAPSI, CAPS for children); one for urgency and emergency care (SAMU); one from Hospital care (inpatient specialized in chemical dependence); one of the psychosocial rehabilitation strategies (Job and income generation service); three RAPS managers ( Mental health coordination, primary care coordination, and teaching research and extension coordination); and nine workers from the intersectoral network: (Social assistance, CRAS, CREAS, Children's house, Guardianship Council, PIM, school, judiciary and Public Ministry).

The interviews were conducted by the researcher individually, recorded on a digital device and transcribed in full. The inclusion criteria of the participants were: accepting to participate in the research by signing the Informed Consent Form; being a coordinator for at least one month in the network service, and, for workers, the criterion was to be employed in the service for at least six months.

The Open Forum was a collective technique used to negotiate data, prioritize the RAPS mission and plan future strategies, and was attended by professionals who usually participate in this area: three RAPS managers and representatives of the Network's components (CAPAS AD, CAPS Nossa Casa, CAPS for children and SAMU).

The practical application of data collection occurred as follows: 1) contact with the field, when the research proposal was presented and discussed, when the interest group agreed to participate in the evaluation; 2) organization of the evaluation process, when the researcher obtained the right of entry and performed the participant observation, with the objective of knowing the reality and the context of the network, when it is also possible to know all the services and sectors that are part of the network that were selected for the research; 3) identification of research participants to conduct semi-structured interviews; 4) joint development and construction, in which semi-structured interviews were conducted; 5 ) expansion of joint constructions, in which other information and materials that could contribute to the evaluation process were introduced - documents, services flowcharts, and meeting minutes; 6 ) preparation of the agenda for the negotiation that organized the information and the construction of the groups so that they could be presented to the participants in the open forum; 7) holding of an open forum, in which the participants had access to the information obtained in the data collection, with discussion, debate and collective construction on the network's mission, knowledge of the current situation of the RAPS, and perspectives for the future of the RAPS.

Thematic Content Analysis was used to analyze the data, which consists of discovering the core meanings of communication whose presence or frequency means something for the analytical purpose. Three stages were developed: pre-analysis; exploration of the material; treatment of results/ inference/ interpretation. ${ }^{12}$ 
The data analysis showed the following thematic categories related to the evaluation of the RAPS: redefinition of care-looking beyond the disease; prevention; family care; social insertion through work and income generation; reduction of prejudice and stigma; connection between services, work processes and people; and harm reduction. In this article, categories on the theme of harm reduction are approached, based on the stages of empowerment assessment: Network Mission; Knowledge of the Current situation; Planning for the future.

This research was based on the principles and guidelines of Resolution No. 466/12, of the National Health Council. The workers were identified with the letter ' $T$ ', accompanied by the RAPS component in which they work. Both letters were followed by Arabic numerals, according to the increasing order of the interview. The study was approved by the Human Research Ethics Committee.

\section{RESULTS}

\section{Network mission}

In this first category, the RAPS mission of caring for drug users was analyzed. The mission of a network means the purpose to be achieved with the work of different professionals. The workers and managers of the municipality under study evaluate that the mission of the RAPS involves a work proposal in the perspective of harm reduction, aiming to minimize physical, social and emotional problems associated with the use of drugs in families. For the research participants, ending the use of drugs is utopia, and actions with this purpose tend to fail: the mission is like that [...] so that it can get better, because it cannot be eradicated [...] but reduces harm, all prevention (T36 Guardianship council).

[...] It is in fact trying to minimize the social and emotional problems that this whole context of alcohol and drug use in families causes. [...] When we are unable to solve everything, at least we try to reduce the harm (T32 Social Assistance).

[...] Guiding is trying to soften, [...] extinguishing the drug is more difficult, it is utopia so if we try to decrease it if we try to recover, reduce the harm (T38 School).

Among the strategies that operate harm reduction, the participants highlight a treatment based on respect for the choices, the user's desire, and social insertion. In this logic, services should be a source of support, awareness and monitoring, without imposing treatment.

The mission is to rescue and make the user aware of the use of drugs and the support role of services, without imposing treatment, but respecting the user's choices and timing. [...] Working to let the user know that it is for their own good [...] that the moment is theirs, the time is theirs, but that we are there, that they are not alone (T28 Harm reduction).

[...] It is being able to offer health care, seeing his issues, which he needs, from the perspective of respecting his desire, from the perspective of Harm Reduction, not only having a vision that he stops using (T2 CAPS AD).

[...] I believe that the main mission is respect and that you treat the differences of choice with the greatest possible care (T34 Social Assistance). [...] I think it is to bring a quality of life, both for the user and for family members, with social insertion in the community, [...] for me the mission of the network as a whole is this [...] people to work towards this common goal (T8 CAPS I). 


\section{Knowledge of the current situation}

In the assessment of the Knowledge of the current situation stage, aspects that facilitate and hinder the achievement of the RAPS mission were identified. Among the aspects that make it easier to achieve the mission, workers highlighted the changes that occurred in the CAPSAD III 24-hour work process. From a proposal predominantly based on abstinence, the service started to work from the perspective HR, operating 24 hours a day, including holidays and weekends. Currently, HR is better understood by network workers. Some changes of the work in the perspective of harm reduction included an expanded view of the person, in their entirety, with reception in the territory, teamwork, reduction of stigma and joint construction of the unique therapeutic project with the user.

[...] It has already assimilated the idea of the harm reduction policy, of not stigmatizing the user, a more extended perspective at the user, to the reception, not simply referring them to the specialized service; serve you in your territory (T1 CAPS AD III).

[...] The team, we understand better what harm reduction is today [...] we worked with the issue of abstinence, there was no other possibility [...], we are doing well in this process, the team is also open to work on harm reduction [...] (T4 CAPS AD III).

[...] The moment we became a CAPS AD III [...], the big gain was to start working without [...] judging, welcoming the individual in their entirety, building the unique therapeutic project together with the user, to be very clear that today it is guaranteed by law, to serve a user in use or not [...] today we attend a crisis, we seek hospitalization as a last resort, we seek to work with the subject in their entirety, it is really an insertion and rehabilitation (T1 CAPS AD III).

Another aspect considered to be a facilitator is the role of the damage reduction team in the municipality. Currently, this team is known as a service belonging to the network, as part of the CAPS ad and Primary Health Care: [...] Now, in fact, the reduction, although it has had some time, is a new service within the RAPS, because it was very dissociated, it worked separately, and I think the articulation is working well, I think it stopped being separate, and became part of it, it is very clear (T5 CAPS AD III).

The harm reduction is with us in the strategy, this is a positive point. [...] I think this is fine. It helped; it helps [...] (T20 Primary Care).

However, among the aspects that hinder the achievement of the mission, the organization and performance of the harm reduction team is identified. For workers, the role of harm reduction in RAPS is still unclear, and their work is often confused with that of CAPS AD. According to the participants, this is due to the use of the same headquarters, the participation of professionals in both teams and the development of activities together in the service and in the community. On the other hand, this new configuration promoted greater integration and communication between harm reduction and CAPSAD: I think it facilitates communication, the work I do not know if it is sometimes confusing, but I think communication is easier. [...] Even because the coordination is the same, [...] because we cannot be concrete enough to think that the physical space is what determines it, but I don't think that it is only the physical space; there was a merger, which will cause confusion in a little while (T6 CAPS AD III).

It would be better if it was in another location. Positive points of the harm reduction structure being here at the CAPS, we have a closer relationship, we have the possibility to monitor cases together, with a better integration, but often confuse what is harm reduction and what is CAPS AD, what role (T1 CAPS AD III).

In a way, the formation of the HR team, enrolled in the CAPS-Ad III, has limited the performance of the RD team, since the cases monitored, in most cases, are those that are being treated at CAPSAD, which may compromise the external agenda for community visits, and prevention actions: [...] The work of the Reduction team has changed a lot, because it ends up that they do so much more in 
the CAPS cases. It could have a more comprehensive look, you know? Within the CAPS it ends up restricting a lot to those who are already in the CAPS, or who should be and are not, and end up doing little prevention, right? (T25 NASF).

[...] Today, the Harm Reduction worker and I went to the family home [family surname] to try to get closer and get to know them. Afraid to receive us, the [user] immediately warns us: "there is no point in wanting to take me to the CAPS, I am not going to" (Field diary).

There are also situations in which the harm reduction ends up making the seam between CAPS AD and ESF, making it responsible for "taking and bringing" information that, many times, do not concern the cases it deals with. [...] Like it or not, we do not belong [to CAPS AD], we only have our headquarters, and many times we take cases there [ESF] that are not ours anymore. It is like this, "as we are here, and already going there", and it is already going along, they already deliver it to us (T28 Harm reduction).

Users also link the performance of harm reduction workers to the work of CAPS, demanding greater dedication to the clarification of the role of the different services, posing daily challenges in the process of building links in the scenes of use: They know that there is a harm reducer worker [users], that has the Reduction, but if you ask what is a harm reduction, they do not know. Many confuse the harm reducer as a CAPS employee. [...] We are there trying to do a reduction job, and he is saying "oh, because I am not going there" (T28 Harm reduction).

It would be good to have some jobs where we can talk, sit with the user, talk a little about the work of Reduction. [...] We still have a lot to learn in the city, and also in Primary Health Care (T27 Harm reduction).

\section{Planning for the future}

The evaluation stage, regarding the perspective for the future, involved the elaboration of proposals to qualify the work in the network, aiming at reaching the mission. The need to invest in harm reduction proposals was highlighted, so that they recover the look at the subjects' potentialities, integrating prevention and health promotion actions.

Working with the potential, going beyond the disease, and this is a daily exercise for mental health workers, because sometimes we tend to focus on the symptom, on drug use and we don't look beyond that [...] prevention, health promotion and prevention are lacking [...], the number of users in the municipality is growing and we no longer believe in prevention (Open Forum).

We, a specialized service, have recently transformed and managed to leave behind the logic of abstinence to work in the logic of harm reduction, [...] work in other areas of your life and not just be in use [...]. I notice that in relation to network care, of the substance user, we still need to evolve a lot in this logic of harm reduction, and not to label the subject (T1 CAPS AD III).

In addition, the need for financial investments in damage reduction teams was identified, such as transportation to carry out actions in the city and localities in the rural areas, as well as human resources for fieldwork: We often have to go to places, inside the city you can even get a bicycle to do the work, but when you have to go to the countryside, we often pay for ticket ourselves and there is no reimbursement [...], or we have to take a ride with the clinic staff, and you have to wait for the shift, go early in the morning and come back only in the afternoon (T27 Damage reduction).

You often have to stop visiting because you are alone. [...]. For us it is risky. [...] The best would be visiting in pairs. If it is a more precarious place, we have to go in threes at least. And one of the things I noticed, that when we talk to the person. they don't accept what we are saying, but our colleague who is on the outside, can take a totally different approach and it will end up working (T28 Harm reduction). 
The need for material resources to qualify fieldwork was also evident. According to one of the participants, work instruments can play a central role in building bonds with users, in addition to being an important strategy for the prevention of communicable diseases. I think we would have to have the instrument, have cigarette holders to take [...]. In the case here, in the case of tuberculosis it is showing up a lot, the consumption of alcoholic beverages, of passing through the tip of the bottle, [...] each one could have his glass [...]. Because it gets easier, you arrive: "I'm a reducer, we came here to talk" [...] "Gee, the guys aren't coming to stop me, they're coming for something else" [...] It's good even for us to come and talk (T27 Harm reduction).

\section{DISCUSSION}

In this study, the RAPS mission, constructed by the participants, represents a care proposal based on harm reduction, with the aim of acting to minimize the physical, social and emotional problems caused by drug use.

Workers and managers demonstrate that they know the importance of HR as a fundamental guideline for networks, considering that a health team may aim to extinguish the presence of drugs within their territories. At the same time, these workers claim that there is work to be done, and it is possible to reduce their damage and promote lasting relationships to different treatment offers, regardless of the level of health care (Primary Care, CAPS AD III, General Hospital, etc.).

Psychoactive substances users have numerous relapses and dropouts during treatment. Thus, what can be desired by the institutions is the reduction of health problems related to the excessive use of drugs, with abstinence being achieved only in a minority of cases. ${ }^{13}$

Studies have already shown that harm reduction strategies can improve the conditions of drug users' lives, and also their permanence in the health and social assistance network in order to avoid marginalization. These actions also allow the user to recognize different ways to minimize the problems related to harmful consumption. ${ }^{8,14}$

Among the strategies that operate from the perspective of harm reduction, participants highlight the importance of respecting the choices and wishes of users, and guaranteeing, within these choices, protection, monitoring and care from the services, without imposing abstinence. as a single treatment goal. They also highlight strategies for social insertion and quality of life of the user, minimizing the harmful effects of drugs, through health awareness and information.

In this perspective, HR is not only a set of techniques in the health field, but an innovative initiative, based on human rights, on the singularity and will of these people. Thus, it proposes to break with previous models of stigmatization of drugs, seeking to create non-coercive strategies for adherence to services, and to establish a welcoming relationship between professionals and users. ${ }^{15}$

Thus, the mission proposed by the participants of this research is in accordance with the scientific evidence on the best practices of user care in the field of psychosocial care, challenging the services to develop integrated strategies for HR, which can lead to improvements in treatment adherence and reduce the fragmentation of care in the RAPS.

In the current scenario, many political changes have been taking place with the establishment of the new Mental Health Policy, approved by Decree 9.761, of 2019, which provides for a separation with respect to care practices based on harm reduction, care in freedom, and guaranteeing the human rights of drug users. The new policy proposes that treatment for chemical dependency should be based on the promotion and maintenance of abstention, with financial investment in therapeutic communities among its guidelines. Such proposals are not in line with the values and principles defended by the Psychiatric Reform, in Law 1.0216/2001, or with the global guidelines for mental health policies, established by the Global Mental Health Plan 2012-2020, which provide for the strengthening of an integrated network and territorial community service. ${ }^{16}$ 
The new anti-drug policy is part of the failed War on Drugs model, which affects the most vulnerable sectors of the population, and has generated several negative impacts, including the considerable increase in violence and repression. In addition, this model is costly and is not able to reduce the market for illicit drugs, nor the impacts caused by drug consumption/use. ${ }^{17-18}$

In view of the setbacks that are occurring in mental health policies at the national level, it is necessary to strengthen care strategies in community services that can combat any type of violation of the rights of users of alcohol and other drugs. ${ }^{19}$ To guide such actions, the National Council of Human Rights (CNDH), through Resolution No.8, rejects the asylum and community treatment model, and reaffirms the principles and guidelines for a national mental health policy that promotes human rights. ${ }^{20}$

This political direction of the CNDH reaffirms the need to promote care practices that value dignity, freedom, autonomy, social experience and inclusion in community services, in which abstinence is not the only form of treatment. In this sense, Harm Reduction presents itself as a fundamental strategy for RAPS, because, in addition to being linked with the guidelines of the National Council for Human Rights and Psychiatric Reform, it presents important scientific evidence that demonstrates its effectiveness in the prevention and promotion of health, treatment adherence, in the context of chemical dependence, as is already observed in developed countries, such as Canada, the United Kingdom, and Australia. ${ }^{14,21}$

Within the knowledge of the RAPS situation, one of the aspects identified as a facilitator for the achievement of the mission is the transition in the care proposals from the implementation of the CAPS AD III 24 hours, a time when professionals began to understand harm reduction better, and to apply them in day-to-day work.

Among the principles of HD, the participants highlight: the expanded view of needs, the reception in the services of the territory with attention to the crisis, joint construction of the PTS, the guarantee of rights and work based on integrality and social reintegration. Such strategies are not exclusive propositions of the HR policy, as they are guidelines of the Brazilian mental health policy.

Regarding the recognition of these strategies as linked proposals, HR demonstrates the expansion of the scope around the understanding of these practices. However, studies show that the perception of HR strategies in networks is still limited, as many professionals restrict these practices to the exchange and distribution of inputs to the detriment of health education actions, bond building, and strategies for guaranteeing rights. ${ }^{22}$

It appears that harm reduction proposals have been little used and discussed in specialized mental health services. A survey conducted at CAPS AD III shows that professionals do not identify the service as a space for operationalizing HR, because they do not work directly with the proposal. ${ }^{13}$ HR strategies are considered less complex and cheaper, in contrast to traditional treatments that are aimed at abstinence. ${ }^{13}$ These findings demonstrate the lack of information and technical support for $H R$, its principles, interventions and how to operationalize it in specialized mental health services.

In the network under study, another facilitator is the existence of a team dedicated to DR reported as an important factor in the multiplication of this knowledge, calling on teams from different levels of the network to update their practices and understandings on the subject of drugs, so that they can, in fact, guarantee the bond and continuity of care.

It is noticed that this link of the harm reduction teams with the health network is under construction. In practice, there are many difficulties that programs encounter to overcome their residual and experimental character, and to integrate with the health system. ${ }^{23}$ One of the important aspects for the integration of the HR teams in the health networks is the organization of the financial resources destined to strengthening this proposal. As of 2006, the PRD underwent changes in the financing mechanisms, and the resources were no longer transferred directly by the National STD/AIDS Program and moved to the state and municipal levels. 
Although such changes are consistent with SUS guidelines, the end result was a broad reduction in the financing of actions. In the case of the PRDs, dependence on local governments may have weakened them or generated heterogeneous patterns across regions. In this sense, new institutional arrangements have been developed, involving HR actions, in an attempt to guarantee its sustainability. One example is the insertion of such practices in CAPS AD or primary care services. ${ }^{6}$

In the experience of the researched network, the articulation between the damage reduction and CAPS AD teams has created some challenges. According to the workers, there was a "merger" between CAPS AD and the HR team, which has presented positive and negative aspects: on the one hand, it promoted greater integration, communication and actions between both teams. On the other hand, it made it difficult to understand the role of HR and, consequently, its way of acting in the RAPS.

In this scenario, there is the challenge to achieve greater autonomy in scheduling the work of the HR team, avoiding situations in which this team acts as a direct channel for updating cases between the CAPS AD and FSH team, which could be agreed upon as responsibility of the CAPS $A D$ matriculation agenda in the ESF.

In the perspective for the future, the research participants highlight the need to invest and strengthen actions aimed at the potential of the subjects and not on drugs, and promote strategies for prevention and promotion of health and harm reduction. Harm reduction actions do not require investment in social policies for prevention and health promotion.

Studies show that the success indicators of a strategy aimed at caring for users of crack and other drugs are: strengthening intersectoral policies with synergism between different sectors; and actions to promote health, citizenship and freedom, based on the principles of harm reduction. Thus, a less harmful relationship to the user is expected due to the use of drugs and, consequently, greater self-care, enabling social inclusion. ${ }^{24}$ Thus, it is necessary to invest in a robust service network, with committed, ethical professionals, and with inclusive care actions, providing autonomy and breaking prejudices. ${ }^{24-25}$

Regarding future objectives, the participants of this research also listed greater financial investments for the HR team, aiming at improving human and material resources for the field work; and transportation between distant areas in the city and rural areas.

These weaknesses are in line with the challenges faced by harm reduction policies in Brazil, which are: the precarious work of professionals; absence or difficulty in monitoring the actions developed; absence of spaces for training and technical supervision and financing problems that affect the sustainability of services. ${ }^{22,26}$

From the perspective of qualifying HR proposals, the importance of the Harm Reducing Agent that transits through the territory of the lives of families in social vulnerability is also understood, relying on this strategy that can give users a voice, inserting them in a complex care network. Thus, in planning for the future of the networks, it becomes important to qualify the HR team in the municipality as the most assertive possibility to work in the field of care for drug users.

The non-inclusion, among its participants, of users and family members among its participants, is a limitation of this study. These actors are very important in the management and organization of the network as they are able to help the construction of local proposals and to see what the worker cannot see. 


\section{CONCLUSION}

This study included the evaluation of the harm reduction strategies in the RAPS. The findings show that, in the care of drug users in the municipality under study, harm reduction is a mission of RAPS, as this proposal is concrete and corresponds to the real needs of users.

In the knowledge of the current situation, it was identified that one of the aspects that facilitate reaching the mission of RAPS is having a better understanding of the proposed harm reduction in CAPS ADIII $24 \mathrm{~h}$. This process resulted in a change in the organization of work and in the care model by promoting improvement in comprehensive care for the user. CAPSAD is considered an important service of the RAPS, capable of strengthening and linking harm reduction strategies in the health network.

Another aspect that facilitates the aim of the mission is the presence of the HR team in the municipality and its integrated performance with the other services of the network. However, a greater understanding of the specificities of HR is necessary, in addition to the autonomy of this team and the strengthening of its preventive proposal.

From the perspective of network investment, it was identified the need to strengthen harm reduction strategies that redirect the focus on the disease and symptoms, in order to recover the subjects' potentialities in a perspective health promotion. In addition, there is an urgent need to prioritize financial investments in harm reduction teams, with human and structural resources, to improve the link of this team with the network and for field work in the territory, as these strategies are the essence of the work of HR.

With the performance of this study, it is possible to indicate that the findings may contribute to the construction of harm reduction proposals integrated into the psychosocial care network, and may provide support to prioritize investments and improvements in the decision making of network managers and workers.

\section{REFERENCES}

1. Andrade TM. Reflections on drug policies in Brazil. Cienc saúde colet [Internet]. 2011 [cited 2019 Apr 15];16(12):4665-74. Available from: https://doi.org/10.1590/S1413-81232011001300015

2. Wiessing L, Ferri M, Bélackova V, Carrieri P, Friedman SR, Folch C, Dolan K et al. Monitoring quality and coverage of harm reduction services for people who use drugs: a consensus study. Harm Reduct J [Internet]. 2017 [cited 2019 July 15];14:19. Available from: https://doi.org/10.1186/ s12954-017-0141-6

3. Jenkins EK, Slemon A, Haines-Saah RJ. Developing harm reduction in the context of youth substance use: insights from a multi-site qualitative analysis of young people's harm minimization strategies. Harm Reduct J [Internet]. 2017 [cited 2019 Apr 15];14:53. Available from: https://doi. org/10.1186/s12954-017-0180-z

4. Wild TC, Pauly B, Belle-Isle L, Cavalieri W, Elliott R, Strike C, Tupper K et al. Canadian harm reduction policies: A comparative content analysis of provincial and territorial documents, 20002015. Int J Drug Policy [Internet]. 2017 [cited 2019 June 12];45:9-17. Available from: https://doi. org/10.1016/j.drugpo.2017.03.014

5. Vearrier $L$, Bioethics $D$. The value of harm reduction for injection drug use: A clinical and public health ethics analysis. Dis Mon [Internet]. 2018 [cited 2019 Jun 15];65(5):119-41. Available from: https://doi.org/10.1016/j.disamonth.2018.12.002

6. Fonsêca CJB. Knowing harm reduction as an ethical propose. Psicologia \& Saberes [Internet]. 2012 [cited 2019 Fev 15];1(1):11-36. Available from: https://doi.org/10.3333/ps.v1i1.43 
7. Ministério da Saúde (BR). A Política do Ministério da Saúde para Atenção Integral a Usuários de Álcool e outras Drogas. Brasília, DF(BR): Ministério da Saúde [Internet]; 2004 [cited 2016 Apr 18]. Available from: http://bvsms.saude.gov.br/bvs/publicacoes/politica_atencao_alcool_drogas.pdf

8. Adamson K, Jackson L, Gahagan J. Young people and injection drug use: Is there a need to expand harm reduction services and support? Int. J Drug Policy [Internet]. 2017 [cited 2019 Apr 20];39:14-20. Available from: https://doi.org/10.1016/j.drugpo.2016.08.016

9. Tuot S, Ngin C, Pal K, Sou S, Sawez G, Morgan P, Mony S et al. How understanding and application of drug-related legal instruments affects harm reduction interventions in Cambodia: a qualitative study. Harm Reduct J [Internet]. 2017 [cited 2019 June 21]:14:39. Available from: https://doi.org/10.1186/s12954-017-0167-9

10. Hyshka E, Anderson-Baron J, Karekezi K, Belle-Isle L, Elliot R, Pauly B, Strike C et al. Harm reduction in name, but not substance: a comparative analysis of current Canadian provincial and territorial policy frameworks. Harm Reduct J [Internet]. 2017 [cited 2019 May 21];14:50. Available from: https://doi.org/10.1186/s12954-017-0177-7

11. Fetterman DM, Kaftarian SJ, Wandersman A. Empowerment evaluation. New York (US): Sage; 2015.

12. Minayo MCS. The challenge of knowledge: qualitative research in health. 11th ed. São Paulo, SP(BR): Hucitec; 2008.

13. Carvalho B, Dimenstein M. Analysis of the Harm Reduction discourses in a CAPS ad III and in a Therapeutic Community. Temas psicol [Internet]. 2017 [cited 2019 June 19];25(2):647-60. Available from: https://doi.org/10.9788/TP2017.2-13

14. Gomes TB, Dalla Vecchia M. Harm reduction strategies in harmful use of alcohol and other drugs: literature review. Ciênc Saúde Colet [Internet]. 2018 [cited 2019 June 15];23(7):2327-38. Available from: https://doi.org/10.9788/TP2017.2-13

15. The Canadian Harm Reduction Network. Canadian AIDS Society. Learning from each other: Enhancing community-based harm reduction programs and practices in Canada [Internet]. 2008 [cited 2019 June 15]. Available from: https://www.cdnaids.ca/wp-content/uploads/Learning-fromEach-Other.pdf

16. World Health Organization. Mental health action plan 2013-2020. Geneva (CH): World Health Organization; 2013 [cited 2020 Feb 20]. Available from: https://www.who.int/mental_health/ action_plan_2013/en/

17. Alvarenga R, Silveira JI, Teixeira DSG. Política de drogas no Brasil no cenário de violações aos direitos humanos. Argumentum [Internet]. 2018 [cited 2020 Feb 23];10:123-136. Available from: http://www.periodicos.ufes.br/?journal=argumentum\&page=article\&op=view\&path[]=20841

18. Flores $A$. Da necessidade de modernização da política internacional antidrogas como forma de efetivação dos direitos humanos. Rev Thesis Juris [Internet]. 2018 [cited $2020 \mathrm{Feb}$ 18];7(2):305-26. Available from: https://periodicos.uninove.br/index. php?journal=thesisjuris\&page =article\&op=view\&path $\% 5 B \% 5 D=11272 \&$ path $\% 5 B \% 5 D=5261$

19. Gomes-Medeiros D, Faria PH, Campos GWS, Tófoli LF. Política de drogas e Saúde Coletiva: diálogos necessários. Cad Saúde Pública [Internet]. 2019 [cited 2020 Feb 28];35(7):e00242618. Available from: http://www.scielo.br/scielo.php?script=sci_arttext\&pid=S0102-311X2019000903001

20. Brasil. Conselho Nacional do Direitos Humanos. Resolução n8, de 14 de agosto de 2019. Dispõe sobre soluções preventivas de violação e garantia de direitos aos portadores de transtornos mentais e usuários problemáticos de álcool e outras drogas. Diário Oficial da União [Internet], Brasília, DF(BR): DOU; 14 Aug 2019 [cited 2020 Feb 21]. Available from: http://www.in.gov.br/ web/dou/-/resolucao-n-8-de-14-de-agosto-de-2019-212175346 
21. Boucher LM, Marshall Z, Martin A, Larose-Hébert K, Flynn JV, Lalonde C, Pineau D et al. Expanding conceptualizations of harm reduction: results from a qualitative community-based participatory research study with people who inject drugs. Harm Reduction J [Internet]. 2017 [cited $2020 \mathrm{Fev} 25] ; 14(18): 2-18$. Available from: https://harmreductionjournal.biomedcentral. com/track/pdf/10.1186/s12954-017-0145-2

22. Inglez-Dias A, Ribeiro JM, Bastos F, Page K. Harm reduction policies in Brazil: contributions of a north-american program. Cienc saude colet [Internet]. 2014 [cited 2019 Apr 25];19(1):147-57. Available from: https://doi.org/10.1590/1413-81232014191.1778

23. Nardi HC, Rigoni RQ. Marginalidade ou cidadania? a rede discursiva que configura o trabalho dos redutores de danos. Psicol Estud [Internet]. 2005 [cited 2019 Feb 25];10(2):273-82. Available from: https://doi.org/10.1590/S1413-73722005000200014

24. Teixeira MB, Lacerda A, Ribeiro JM. Potentialities and challenges of an intersectoral public policy on drugs: "With Open Arms" Program of São Paulo, Brazil. Physis [Internet]. 2018 [cited 2019 July 16];28(3):e280306. Available from: https://doi.org/10.1590/S0103-73312018280306

25. Siqueira DF, Terra MG, Vieira LB, Moreschi C, Mello AL, Soccol KLS. Care actions for the relatives of users of psychoactive substances: the perspectives of professionals and families. Texto Contexto Enferm [Internet]. 2019 [cited 2019 June 10];28:e20180022. Available from: https://doi.org/10.1590/1980-265X-TCE-2018-0022

26. Batista CB, Vasconcelos MPN, Marcelo D, Queiroz IS. Permanent education on harm reduction: the experience of Psychosocial Care Course in Alcohol and other Drugs. Interface (Botucatu) [Internet]. 2019 [cited 2019 May 15];23(14):e180071. Available from: https://doi.org/10.1590/ interface. 180071 


\section{NOTES}

\section{ORIGIN OF THE ARTICLE}

Article extracted from the thesis - Empowerment evaluation of the psychosocial care network in the care of drug users, presented to the Graduate Program in Nursing, at the Universidade Federal do Rio Grande do Sul, in 2019.

\section{CONTRIBUTION OF AUTHORITY}

Study design: Santos EO, Pinho LB.

Data collection: Santos EO.

Data analysis and interpretation: Santos EO, Pinho LB.

Discussion of results: Santos EO, Pinho LB, Eslabão AE, Medeiros RG.

Writing and / or critical review of the content: Santos EO, Pinho LB, Eslabão AE, Medeiros RG.

Final review and approval of the final version: Santos EO, Pinho LB, Eslabão AE, Medeiros RG.

\section{ACKNOWLEDGMENTS}

CAPES for the Post-Graduate Research Fellowship of the first author.

\section{APPROVAL OF ETHICS COMMITTEE IN RESEARCH}

Approved by the Ethics Committee in Research with Human Beings of the Universidade Federal do Rio Grande do Sul, opinion no. 2,322,028 / 2017, Certificate of Presentation for Ethical Appreciation 72657617.7.0000.5347.

\section{CONFLICT OF INTERESTS}

There is no conflict of interest.

\section{HISTORICAL}

Received: September 09, 2019.

Approved: March 09, 2020.

\section{CORRESPONDING AUTHOR}

\section{Elitiele Ortiz dos Santos}

elitiele_ortiz@hotmail.com 